Section one is a host-fungus list, providing an account of 219 species of Rhododendron and their 518 putative pathogens or saprobionts. Plant parts affected and (American) common names of diseases are included.

Section two displays a host-fungus list arranged by locality (states of USA, countries elsewhere, with curious listings of for example 'Germany' in addition to 'West Germany', and 'England', 'Scotland', 'Wales' in addition to 'United Kingdom') in which the pathogens have been reported. Browsing through this list quickly aceentuates the US bias of this book. Whereas China (the centre of Rhododendron diversity) is covered on one page, listing 41 taxa of Rhododendron and a similar number of fungus taxa, the US is covered on 15 pages, listing over 100 Rhododendron taxa and around 300 taxa of associated fungal pathogens and saprophytes.

Section three is a fungus-host list including some systematic information (order or class) with host range, location and literature references supplied.

Section four is an alphabetic listing of the fungi treated in the book. In addition to plant parts affected by the fungus, host range (including non-Rhododendron hosts) and distribution, this also contains helpful taxonomic information, synonyms and literature citations. This is possibly the most informative part of the book.

The book is concluded by an index of fungal species epithets including a useful reference for synonyms (Section five) and a bibliography of 540 mainly historical literature citations (Section six). Few current references are included, the latest two being from 1993. Sadly, many non-English references are riddled with typographical errors.

There are no illustrations, descriptions or keys for either the fungi or the host plants, a fact which limits the usefulness of the book to all but specialized plant pathologists or Rhododendron taxonomists. However, and despite the US bias discussed above, the information may be profitable for statutory services dealing with plant import inspections elsewhere, and as a reference work for plant pathologists worldwide. A software copy of the relational database from which the book was produced would nevertheless be much more useful.

\title{
S. HELFER
}

Dictionary of Plant Names in Latin, German, English and French. Hristo Nikolov. J. Kramer in der Gebrüder Borntraeger Verlagsbuchhandlung. Berlin, Stuttgart. 1996. vi +926pp, $14 \times 22 \mathrm{~cm}$. ISBN 344350019 6. DM188; US\$128.

Most well-equipped botanical libraries house a global representation of dictionaries of vernacular plant names. Often, because of the sheer magnitude of the subject, they are specialized reference works for a specific readership. For example: the five volumes of Wörtherbuch der Deutschen Pflanzennamen (Mazell, 1943-1958); Plant names of medieval England (Hunt, 1989); the Spanish Nombres Vulgares I \& II (in Archivos de Flora iberica nos $4 \&$ 7, 1992, 1996). The most recent addition to this 
genre attempts to provide a compact, wide-based, 4-language dictionary for everyman. The Preface by the Bulgarian author states: "[it] is intended for students, professors, scientists, physicians, hobbyists and others interested in botany. It is a listing of 14,500 generic names ... in c. 600 families of plants, bacteria included .... Lower plants are represented by many genera'.

The first section lists Latin botanical names alphabetically together with their family and common name(s), if such exists; the complementary second section gives vernacular names and the Latin equivalent. Bearing in mind the wide scope of the work and the fact that it appears to be virtually a one-man venture, the coverage of names is certainly quite impressive. Scottish readers will note with satisfaction the differentiation between 'Bluebell of Scotland: Campanula rotundifolia' and 'Bluebell of England: Endymion non-scriptus'. The general browser will come across some very recherché vernacular names: 'Torrubia longifolia: Long-leaved Blolly'. The common names are sometimes presented, at least for the English-speaking user, in a rather curious way: 'Tree Nettle European: Celtis australis'; 'Grass Meadow Hard: Scleropoa'. In the Latin-name section are a large number of generic names without any vernacular name and with one constituent species given; often the latter are the type species of the genus though this is nowhere indicated. These entries seem quite superfluous in a dictionary of common names.

The format and typography make it an easy book to use, though tighter editing and excision of superfluities would have much reduced the volume of print: for example, the entry for Cyphomandra gives 'Cyphomandra D, Cyphomandra E, Cyphomandra F'. Throughout, it is not at all difficult to spot infelicities or sins of omission or nomenclature. This is almost inevitable without meticulous crossreference checking, consultation of many more reference works than those cited in 'Literature', and without input from a platoon of international specialists. The Preface gave an indication of the scope and aims of the work; for the objective reader it raised doubts about its credibility and whether the international botanical community really needed it. These doubts were not dispelled in reviewing it; the canvas was just too big.

I. HEDGE

Stearn's Dictionary of Plant Names for Gardeners. W. T. Stearn. London: Cassell. 1996. 363pp. ISBN 0 30434782 5. £14.99 (softback).

This book is an interesting compendium on the origin and history of a selected 6000 botanical names most likely to be encountered by gardeners and horticulturists. The information in it draws on the wealth of knowledge gained by Stearn's own research of botanical and horticultural literature over the last 60 years. Also listed are 3000 of the most widely accepted vernacular names, cross-indexed to their correct botanical names which will be an invaluable reference guide. Both the sections are prefaced 